R. B. BRANDT

\title{
CONSCIENCE (RULE) UTILITARIANISM AND THE CRIMINAL LAW
}

\section{INTRODUCTION}

In this paper I wish first to contrast a society's morality with its legal system, and then to explain (1) whether and in what way a conscience (rule)-utilitarian theory of morality has implications for what a morally acceptable system of criminal law might be and (2) what a utility-based criminal law would look like, as compared with the present criminal law in the U.S.

Begin with an explanation of "a person's morality". I propose we explain this as comprising (1) his intrinsic aversions to doing certain types of things (like telling lies), (2) his disposition to feel guilt or remorse if he acts contrary to these aversions, (3) his disposition to feel disapproval - indignation, coolness - toward other persons who do (provided, in the cases of (2) and (3) there is no "excuse" - see below), (4) along with a belief that these attitudes are justified in some appropriate way. On this view of "morality," If a person says, " $A$ is morally wrong," he is expressing an unfavourable syndrome of this sort toward actions of the kind $A$. A person's total syndrome of this sort, toward actions, is his conscience.

Then a person holds a normative rule-utilitarian theory about morality if he affirms roughly (there are variations ${ }^{1}$ and I shall

\footnotetext{
1 Among those who roughly hold a rule-utilitarian theory of some sort: Francis Hutcheson, Bishop Berkeley, J. S. Mill, J. O. Urmson, Kurt Baier, J. D. Mabbott, Stephen Toulmin, R. F. Harrod, Kai Nielsen, A. MacBeath, C. A. Campbell, Marcus Singer, P. H. Nowell-Smith, John Harsanyi, and (probably, at least at one time), Wilfrid Sellars, early John Rawls, may be mentioned. Some of the above might object to being so classified, and doubtless there should be additions.
} 
develop the concept more fully later) that a morality is really justified if and only if the teaching and prevalence of it (its typical conscience) in a society would maximize the general well-being. Notice that conscience-utilitarianism in this sense is a thesis about morality: one might also be a utilitarian about justified ${ }^{2}$ systems of criminal law, holding, in part, that a justified law's declaring certain types of action as "offenses" and requiring and implementing punishing them in a certain way must maximize public benefit. But whether a system of laws is morally justified if and only if this is true may be a different matter.

A conscience-utilitarian about morality need not hold a utilitarian thesis about justified law; and, of course, the reverse is also true.

Nothing has been said about how a conscience-utilitarian thesis about justified morality might be supported, or even about the reasons for explaining "morality" or "morally right" as I have done.

What is the actual morality of a given person, or the typical or average morality of a whole society, is relatively easy for a sociologist to determine. Not so for a determination of what kind of morality is justified, which requires philosophical argument. Conscience-utilitarianism as a theory is a development of this. So the truth of conscience-utilitarianism as a normative thesis about morality cannot be determined by the methods of sociology.

Explanation of "the criminal law in the City of Ann Arbor" is in this respect much the same as "the actual morality of this person (or society)." It can be determined empirically by lawyers or legal scholars. It consists of the statutes, applicable in Ann Arbor - federal, state, or local, as interpreted by the courts - statutes (and some lesser practices) which identify which kinds of behavior are "offenses" and which specify the penalty affixed to each type of offense,

2 How one should explain, or defend, a conception of "justified" legal systems is a further question, which I do not address. "Morally justified legal system" I do explain in what follows. 
including, of course, the range of penalties among which the courts have a discretion to choose. The criminal law in the city of Ann Arbor is thus an observable fact. Not so the justifiable, or the morally justifiable legal system, although whether a given legal system maximizes public benefit may be so, at least in a large part.

\section{MORALITY VERSUS LEGAL STATUTES}

What is the connection between something being actually condemned as immoral in a given society, and its being illegal in that society? The answer to this question is not quite simple.

(1) There are evidently some things that are contrary to a person's or a society's morality, and which are not illegal. For instance, a given social morality may condemn telling harmful lies, but that may not be a criminal offense. Again, failure to make gifts for charitable purposes, say to the truly needy, may be morally condemned, but it surely does not infringe the criminal law (although making a gift will result in a tax deduction). In some states there are "good Samaritan" laws, requiring a motorist to stop and give aid if he observes an accident or distress; but such laws are not universal, and they are very specific about what must be done and when.

The reason for this difference is doubtless that the law as we know it must operate by statutes, procedures, and relatively severe sanctions. Any moral appraisal of the law must take this fact into account.

(2) There is a part of morality not mentioned above: that some acts give the agent some personal satisfaction, and are admired/praised by the society in which the act was performed "supererogatory" acts, ones that are viewed as socially desirable but not morally required although they would be required but for the cost to the agent. For instance, a physician might go into a plague-infested area, to give aid, when morality would hardly declare he is morally obliged to go, at a risk to himself.

The criminal law does not have such a department of praise; it is limited to condemnation and penalties. 
(3) A person cannot be penalized for an offense if the law prohibiting that kind of action has not been publicized in advance. This is in general not true for morality; it is supposed that at least every adult knows the difference between right and wrong without the benefit of a specific announcement beyond ordinary educational processes. (Children, however, are morally excused when they cannot have been expected to know; and if a chain of reasoning intervenes between the presumedly widely known principles of morality and a particular action, even an adult may not be supposed to be familiar with this and may not be condemned for an infraction, especially on matters about which there is moral disagreement.) Roughly, the difference with the law is that it is not supposed that any special announcement must be made in order for a person's action to be within the scope of morality.

A reason for this requirement of the law is made clear by a famous example, of a law in Los Angeles requiring anyone convicted of a felony in another state to register with the L.A. police within a week after arrival in Los Angeles. How could new arrivals be expected to know of this law? The law was declared unconstitutional. It is hardly morally justifiable to punish someone for doing what a reasonable person would not believe to be illegal. There could hardly be public benefit in enforcing such a law.

(4) More importantly, the law gives very little place to individual reflection in determining what is the law. In partial contrast to what has just been said, morality gives a large place to personal reflection in deciding what in particular is moral. If an individual thinks through his principles that bear on a certain case, and concludes he ought to do so-and-so, it is thought this is what he morally ought to, or at least morally may, do - roughly "follow conscience" (although a person's reflection and principles of conscience may so diverge from what we think of as decent and rational that his results throw moral doubt on him and his thinking/ conscience, rather than underwriting his conclusion - we may think a person was rationalizing: doing what he really just wanted to do). Thus, in matters of morality the individual agent is ideally in a position a bit like that of an appellate judge in courts of law 
- a judge who may decide on an interpretation of the law in view of (roughly) what he supposes is the benefit-serving purpose of the adoption of a statute and is coherent with the themes of law as a whole. So, in morality, the individual is given leeway in deciding what moral principles require for a given case. We shall see that this is necessary at least in a conscience-utilitarian type of morality, for the manifest moral duties of a person do not identify what is to be done when there is conflict of moral rules - the agent's thinking is necessary to decide this. But the individual's reflection does not have this standing in the law: proponents of a "right to life" are not free to disobey a court order not to attack or even to obstruct the business of a center providing abortions, whatever their moral commitments. In this, the stand of the law is largely right: if acts are criminalized only in cases where there is largely consensus about their harmfulness, the criminal law may have a helpful teaching function. Still, we should not draw this distinction too sharply; the law itself recognizes moral commitments as affecting legal duties in some cases, e.g., scruples about serving in the armed forces in time of war. There is a large literature ${ }^{3}$ on this. There is also, in the law, scope for moral judgment of agents of the law: of policemen about when to make an arrest, of prosecutors about whom to charge and for what offense, of judges about what sentence to pronounce within certain limits, and so on.

(5) To continue with a somewhat similar point, an action is not illegal if the law is not clear and explicit (with some reservations about future adjudications). But in morality, there are various levels of salience. Some types of action have been well-impressed on consciences since childhood: not telling lies, not stealing, not injuring other people. We automatically feel guilty if we knowingly do one of these things. (W. D. Ross claimed that there are just seven self-evident principles of obligation.) Other matters are not so clear.

3 See, for instance, Kent Greenawalt, Conflicts of Law and Morality (New York: Oxford University Press, 1987). 
How much of my income should I give to help the needy? If my son needs money, am I free to give to him what otherwise might have gone to help the truly needy? Should I support a tax code which provides for promoting equality of well-being? (In thinking about these issues, a moral person may even find she must deliberate about what someone's "well-being" consists in.) One may think these issues through, and come to a conclusion which one then adopts into one's scheme of thinking about obligations. Thereafter one is inclined to feel guilty or disapprove of others on these scores. In this sense such conclusions become a part of one's "conscience" or "morality". But one might not, at least initially, feel guilty about acting contrariwise, as one would about telling a lie, and one would be unlikely to feel indignant at someone else for not acting in conformity with one's newly-endorsed principles (like one favoring equality of incomes). In this sense the salience of different moral "rules" may vary. (In a different sense, we might say that one moral rule is "stronger" than another if the aversion to contravening it is stronger, the guilt feelings at contravention are more pronounced, and the disapproval of those who infringe is more forcible.) There is no parallel to this complexity in the law, although one law may in a sense be stronger if the penalty for infraction is more severe, and, of course, one prohibition of the law may be well-known and other laws seem arcane. It is true that some laws are just trivial, but, even if so, they are still the law (although police/prosecutors may choose to ignore them).

But it would be a mistake to draw the line between morality and the law too sharply. ${ }^{4}$ In some cases, other than those already mentioned, moral considerations enter explicitly into the law. Consider, for instance, the excuse of duress in the law, e.g., that

${ }^{4}$ This was a recurring thesis in the work of Conrad Johnson. See his "Toward a Cautious Return To Natural Law: Some Comments on Moral and Legal Obligation," Western Ontario Law Review 4 (1975): 31-49; "Moral and Legal Obligation," Journal of Philosophy 72 (1975): 315-33; and Moral Legislation (Cambridge: Cambridge University Press, 1991). 
an unlawful act is excused if done in response to a serious threat (to self or others close to one) by another person. The Model Penal Code states that an unlawful act is excused if done in response to a threat such that "a person of reasonable firmness in his situation" would be unable to resist. But what does this clause mean? It seems that what a person of "reasonable firmness" would not resist comes down to something that a person of good character would not resist. As George Fletcher has remarked, a decision on this "is patently a matter of moral judgment about what we expect people to be able to resist in trying situations." ${ }^{.5}$ It is assumed that a "reasonable man" would not kill in response to a slap on the face. A more general and more important point: we may also say that a person is not thought guilty of a crime unless in the total context it is reasonable to believe he would not have done what he did if his character, not only his moral motivations, but his lawabidingness, had not been below the standard we expect of decent people. So, if someone does something illegal from inadvertence, or nonculpably mistaken beliefs about the situation, etc., he will not be penalized by the law. The same thing, of course, is true of morality: a person will not be the object of moral indignation for what he did if his action did not manifest a defect of character. (In both cases, a partial justification of sanctions, moral condemnation or legal punishment, is that the agent's motivations are defective and need improvement. $)^{6}$

(6) The law is more concerned with the actual consequences of one's act than with one's intentions and motives (although the presence of intent is normally a condition of having committed a crime). Thus, if I strike a hemophiliac, quite ignorant of his physical

5 George Fletcher, Rethinking the Criminal Law (Boston: Little, Brown, and Co., 1978), p. 804. See also his "The Individualization of Excusing Conditions," Southern California Law Review 47 (1974): 1269-309.

6 See my "A Utilitarian Theory of Excuses," Philosophical Review 78 (1969): 337-61, and "A Motivational Theory of Excuses in the Criminal Law," Nomos 27 (1985): 165-200, both reprinted in Morality, Utilitarianism, and Rights (Cambridge: Cambridge University Press, 1992). 
condition, and with no intention to cause serious injury, morality will accuse me of nothing more than an assault. In the law, if he dies, I may be guilty of a serious form of homicide. Or, if I am involved in a robbery and in a subsequent exchange of gunfire someone is killed, even if I do not shoot at anyone and do not even have a weapon, I may be guilty of murder. (Morally, I am surely condemned only for participating in a robbery.) All "strict liability" offenses are of this sort. Here the law seems open to moral criticism, as it stands.

(7) Any disparity between the requirements of law and those of morality may be partially bridged for some people, by the reflection that one has a prima facie moral obligation of some weight, to obey any law if it has been adopted in a democratic society, and like most such laws is apt to be socially beneficial. This is controversial, and it may be held that there is no moral obligation at all to obey a law, if doing what the law requires is not morally obligatory, independently of the law. ${ }^{7}$ We shall see whether such a view is an implicate of a conscience-utilitarian theory of morality. But, even if it is, the weight of any prima facie obligation remains to be determined, and obviously it may not be easy to identify what is one's real obligation, everything considered. One might think that the force of such a prima facie obligation is just that, when one is not aware of countering considerations, one should automatically obey the law, assuming one knows what it is. So, faced by a "Stop!" sign, one should stop unless one has thought of countering considerations (like not wasting time and gasoline by stopping when there is clearly no intersecting traffic in sight, but one might wonder if there is even a prima facie moral obligation to obey a law forbidding pedestrians from crossing

7 For discussion of the complications, see Donald Regan, "Law's Halo," Social Philosophy and Policy 4, 15-30; also M. B. E. Smith, "Is There a Prima Facie Obligation to Obey the Law?," Yale Law Journal 82 (1973): 950-76; Joseph Raz, The Authority of Law (Oxford: Clarendon Press, 1979), pp. 233-49. 
a street against the lights, as was enforced in California and Washington, if one can see there is no traffic coming.) Moreover, in contrast to any prima facie obligation, it may well be thought to be immoral, everything considered, to obey a certain law, e.g., requiring serving in the armed forces in a war in which one thinks one's country ought morally not to be engaged. There is a large literature on this conflict. ${ }^{8}$

\section{THE CRIMINAL LAW AND CONSCIENCE-UTILITARIAN MORALITY}

With these distinctions made, there is a question of how much difference there is between the actual statutes and careful enforcement of the law including its sanctions, and the requirements of at least the form of conscience-utilitarian theory about morality which I tend to support - that an act is morally wrong if and only if it is contrary to a morality (conscience) the teaching and prevalence of which would maximize the public good.

In the case of the law, some authoritative body, with the power to enforce its dicta, has declared that any person who has been shown, in an appropriate proceeding, to have done something speci-fied by the statutes, as interpreted by the courts, will have imposed upon him some unpleasant penalty such as a fine, a duty to perform some community service, to undergo some treatment like behavior therapy, or, much worse, be confined to a penal institution for a specified period of time (with possibly some discretion in the hands of a parole board, about how much the specified period may be shortened). All this is an act of government - indeed, one which brings harm to some people, the convicted criminals -, and, as such, clearly subject to appraisal by a correct morality (here supposed to be the one affirmed by the conscience-utilitarian theory). If one holds the conscience-utilitarian theory, one can say that the enactment or enforcement of

8 See, for instance, Kent Greenawalt, op. cit. 
a law is not morally right, if it contravenes the rule-utilitarian standard of right action.

There is a complication here, however. This rule-utilitarian theory about morality proposes that an act is wrong if a morality (so intrinsic motivations to avoid that sort of action, guilt/remorse feelings if one fails, and indignation, etc., toward others who fail which in each case is without an excuse) forbidding it - other things being equal - would maximize public benefit. This conception seems to allow that the requirements on conduct of even a maximally beneficial legal system need not coincide with those of such a morality. Suppose a total legal system is so devised that its operation will (or expectably will) maximize the public benefit, thereby conforming with the requirements of a utilitarianism (like Bentham's) about the law. Will its demands on action necessarily coincide with those of an optimal moral system? In the preceding section we have seen some disparities between morality and the law. For one thing, the law is necessarily a bit heavy-handed, requiring statutes, procedures, and (as things are) a rather restricted set of sanctions such as imprisonment. Thus it is quite clear that the law's declarations of offenses and its punishment of offenders can be inappropriate for many "morally wrong" actions, such as failure to give to charity, racist attitudes in interpersonal relationships, failure of professors to prepare adequately and to grade equally, and so on, each such action justifiably arousing guilt-feelings and indignation of others ("justifiably" because, on the conscienceutilitarian view, the motivations, disapproval of others, etc. will maximize public benefit). Now the Benthamite utilitarian about law is not asking whether moral sanctions etc., of certain actions will maximize public benefit, but whether the total legal sanctions, including sentences of imprisonment and identification of offenses and the procedures for assessing guilt, will maximize public benefit. Severe sanctions would be out of place for many moral offenses, and the sanctions of morality (such as disapproval by others) would doubtless not affect many potential criminals whom the law would like to deter. So, if we want to morally appraise a criminal statute or the imposition of a criminal punishment, we 
have to take this larger picture into account. It is one thing to say that a certain morality will maximize public benefit, and quite another thing to say that the operation of a certain legal system will maximize public benefit as compared with other legal systems operating with essentially the same restrictions.

It seems, however, that a rule-utilitarian about morality will probably want to affirm a prima facie moral obligation to obey every law, if it has been authorized by a democratic society and if, as a typical instance of such laws, it is likely to maximize the general benefit. For the idea will be that support of such a system by moral sanctions (moral rules) will do more good than by negative moral attitudes, or no attitudes, in the society; support of a democratically enacted legal system may itself be expected to be instrumentally a good thing. Presumably legislators, although they may subscribe to no moral theory and may not be thinking about morality at all (although sometimes, e.g., when voting about antiabortion acts, they at least normally vote their moral commitments), vote for a law (etc.) mostly in the belief that law will do the best for the public well-being (in some sense of "well-being") - unless, of course, they are thinking about re-election and think a vote for a certain law would help in this. So it may be hoped that, usually, laws are aimed to comport with the utilitarian legal ideal - law and law enforcement to maximize public benefit, and so far merit a prima facie moral obligation to obey them. It is a very different question, however, whether citizens have not a moral duty to do what they can to get the laws changed, in a direction more publicly beneficial.

What clear meaning can be attached, then, to a statement that a given part of a system of criminal law is "immoral"? I suggest we can say this: the enactment, support, and implementation of a system of criminal law are morally in the clear only if these are justified by a (conscience-utilitarian) moral standard, and only if a justified morality would approve of these things, taking into account the fact that a legal system is necessarily restricted in certain ways. So a justified morality, we may suppose, will condemn "cruel and unusual punishment" and will condemn enactment and imple- 
mentation of any legal system which does not. More generally, a (conscience-utilitarian) morality will require of a system of criminal law that the punishments for certain offenses be ones that would approve themselves to optimal moral aversions/emotions including indignation, in view of the benefits of there being such moral aversions/indignations toward such punishments for such offenses, in the society, as compared with no such or different aversions, etc. Thus we can say that the enactment and implementation of a certain legal system is not morally in the clear unless, given the methods available to the law (punishments of some sort) and its aim (reforming, but primarily maximizing the public benefit by deterring anti-social behavior), it would be approved by an optimal (conscience-utilitarian) morality. Manifestly some feature of a given system of criminal law could fail this test - for instance, if it manifestly ignores the well-being of the convicted who are capable of improvement by therapy and instruction as contrasted with being thrust into an unfriendly penitentiary in which they can learn more criminal ways from other inmates! $!^{9}$ So, in the end, a conscienceutilitarian will think that a given system of criminal law is not "good morally", unless its enactment and implementation will meet this standard. Otherwise that law is just an arbitrary imposition, for no morally justified reason. (This is not to say that bad laws are not laws at all, as some "natural law" theorists may have main-

9 The New York Times, Sept. 15, 1993, A-15, reports a 17-year-old (undoubtedly black) boy in Thomaston, Georgia, being sentenced to three years in prison for allegedly stealing (he had entered a school building without authorization and a box of ice-cream bars was found missing from the cafeteria) ice cream bars, after plea-bargaining with no advice from a court-appointed lawyer who was busy with another case. The legal system of Georgia of course does not mandate such a sentence in such circumstances, but it did permit it, and the operation of the system had that result. (As a result of the efforts of the NAACP and newspapers, the boy, after ten days in prison, was released on $\$ 15,000$ bail, for a new hearing.) I suggest that this sentence (and indeed probably the proceeding) was outrageously immoral. What can be done to prevent such occurrences? 
tained.) One may naturally ask, however, how it could be that a legal system, with statutes and implementation intended by legislators to maximize public benefit, could possibly fail to meet the conscience-utilitarian moral standards. We must go into this.

Compared with the appraisal required by legal systems, the job of identification of morally permissible actions by a conscienceutilitarian moral system is relatively simple, despite what I have said about the role of personal reflections in morality, and various degrees of salience in moral principles. To explain this, however, we must go a bit beyond our initial description of "conscienceutilitarianism" as the view that a morality is correct if its prevalence and teaching would maximize public benefit. Yet all the conscienceutilitarian moralist has to know, to determine whether it is best for persons to have a certain level of motivation in certain directions, e.g., not to steal, injure others, etc., is simply to know whether there would be more public benefit if such a rule were taught and widely prevalent, as compared with no rule at all or a somewhat different rule. Thus the major thing one has to determine is whether it would be better if everyone, say, were motivated to tell the truth (with various exceptions), as compared with there being no rule of conscience on the matter. Or, for cases of conflicts of motivation, one has to know whether it is better for the public if people are more motivated to tell the truth versus avoiding injuring others (to a certain degree). We hardly need a social science survey to determine this. As Bishop Berkeley (the first person to state explicitly an essentially conscience-utilitarian theory) wrote: The basic moral principles "to right reason evidently appear to have a necessary connection with the Universal well-being". ${ }^{10}$ The main themes in core morality will not be hard to identify. The main problem arises for cases for which the main prescriptions give conflicting imperatives. For such cases we may have to decide (according to the conscience-utilitarian) which of the basic rules should have priority, or possibly decide that a more complex rule

10 George Berkeley, Passive Obedience (1712), reprinted in Berkeley, M. W. Calkins, ed. (New York: Charles Scribner's Sons, 1929), p. 436. 
would do better than either of the basic principles, in view of prospective public benefit. (Morality also makes a distinction about which one of various failures to conform to morality is worse morally, to be more strongly reprehended. This order of moral badness will presumably reflect the order of priority about moral duties - whether the obligation to do one thing is stronger than the obligation to do another. (Actually, things are doubtless a bit more complex, since the moral badness of an act depends, in the total context, on whether the act shows that the agent's conscience is defective to a certain degree, insensitive to one or more obligations.) Here thought is necessary: Would it have better results, everything considered, if the one rule prevailed and was taught as having greater force, where there is conflict? Or suppose there is reason to think that many people will in fact not follow the rule that seems best on this basis, possibly for the reason that they do not make the same judgments about which rule should have priority, or perhaps just because they are selfish. It is not clear how much difference this should make. Even if there is a lot of dishonesty in business, it would be recognized that it is a good thing for there to be a public standard of honesty, one that is argued for, for familiar reasons. It might be argued, that, in case of such conflicts, nobody will know what is agreed on and that there will not be a public standard; but at least it seems Berkeley was right that on the main items of a core morality there will not be disagreement, and we shall be able to predict, and count on, what a moral person will do, if he is intelligent enough to follow reflections about the public good. So, given a conscience-utilitarian theory, inferences as to what is morally required, from reflections on the probable impact of a specific item of a morality on the benefits of the total system of moral motivations, should not be too difficult, or beyond the powers of thoughtful people with normal experience with social living.

Now one of the jobs of the conscience-utilitarian theory is to provide an appraisal of the actual system of criminal law. That is not so easy, for reasons we have seen. For it requires the determination of whether society would be better off not only in view 
of the benefits of the law's prohibitions and sanctions, but also, in a secondary way, in view of the benefit of people being morally motivated (etc.) to give the system support.

The major problem about the morality of our criminal law, however, is not in such a refined question as whether morality's support of a given legal system would serve the public good maximally, but the simpler question of which system of criminal law - or its statutes, procedures, and sanctions - would serve the public good maximally. A partial answer to this question is not hard, since it requires only a decision about which kinds of conduct should be an "offense": deliberate killing, rape, theft, deception in business transactions, forgery, etc. The law also has to decide the order of badness of these offenses (which I have suggested also has to do with morality), which in the case at least of the law means the relative magnitude of the harm done to an individual or the public. But, much more difficult, it has to decide what to do about them - i.e. what penalty should be attached. This is a most serious, and also a very difficult question.

In order to get a picture of the seriousness of the problem, we must ask: What sorts of punishments does the law actually mandate? Consider, as an example of what is actually done, the Federal Sentencing Guidelines (effective November 1, 1987). ${ }^{11}$ This program lists 43 "offense levels" with prison terms varying from 0 months to life. The more interesting basic penalties, for a first offense, are: (1) murder, life imprisonment; unpremeditated homicide, 10 years; involuntary homicide (e.g., drunk driving), 6 to 15 months; (2) rape with force or threat, 6 years; statutory rape, $11 / 2$ years; (3) kidnapping $31 / 2$ years; (4) assault intending bodily harm, 3+ years, increased to 4 or 5 if a firearm was used or serious injury caused; (5) robbery, 2+ years, increases to $4+$ if injuries caused or large sum taken; (6) burglary of a residence, 2 years; (7) perjury, one year; (8) various offenses with smaller penalties up to one year: embezzlement (more if a large sum), bribery of a witness,

11 U.S. Sentencing Commission, Supplementary Report, Washington, D.C., 1987. 
force or threats to suppress civil rights, blackmail, insider trading, fraud. (9) All attempts to commit a crime, the same as for the basic offense. (This item may be strongly criticized, but I shall ignore it.)

Further, if the normal sentence is not more than six months imprisonment, the judge has the discretion to substitute probation (up to five years), during which time the individual may be required not to commit another crime, to report regularly, possibly live at home and perform community services, etc. In the State of Minnesota probation is permissible when the normal sentence is not more than two years.

Moreover, the above sentences are for first offenses only. The listed prison terms are to be increased by approximately one-third for each previous conviction of a felony, perhaps because the individual is thought to be more dangerous, more liable to commit another crime. (This view can reach absurdities: the Supreme Court refused to review the case of Rummel v. Estelle; the defendant had been given a life sentence, as a third offender, for three crimes of obtaining money under false pretenses, in the total sum of $\$ 120.75$.) Would it make a difference in morality if an offense is a second: say, justifiably produce stronger guilt-feelings in the agent, stronger indignation by others? One might think less of a second offender, since the second offense tends to show something about his character; and hence predictive of the future if nothing is done; but morality is essentially about act-types, and a second offense is hardly an act-type, although on reflection one might conceivably think so and this determination might become part of one's conscience at a deeper level.

Moreover, a judge is permitted to increase the normal sentence for various reasons: e.g., that the victim was vulnerable on account of age or physical/mental condition, or if he was physically restrained. (Morality, which is not restricted by statutes, will regard these as different offenses.) On the other hand, the normal sentence may be reduced if the criminal voluntarily surrendered to authorities, made restitution, or assisted in recovering gains from the crime. (A conscience-utilitarian morality may regard these behaviors as 
showing less defect of character than does the basic offense, and so deserving less reprobation.)

What sense can be made of this hotchpotch of sentencing rules, other than that much of it is traditional? Could we show that these regulations are justified as maximizing the public good? Suppose we think that the various crimes differ in their harmfulness (perhaps corresponding to the order of the size of penalties attached) - although we might well doubt this - and suppose we suggest that these relative sentences might be justified in that they provide more deterrence for the more serious crimes. Should one say that rape is twice as worthy of deterrence as kidnapping or assault (twice as bad as an assault breaking both one's legs?) or robbery, three times as worthy of deterrence as residential burglary, and six times as worthy as perjury? ${ }^{\text {?2 }}$ This is surely open to question.

Even if one thinks the order of severity in sentences conforms roughly to the order of harmfulness of the crime, another step is needed to justify the practice of the criminal law: to explain how the public good is maximized by these different sentences. ${ }^{13}$ Of

12 See Michael Davis, "Setting Penalties: What Does Rape Deserve?" Law and Philosophy 3 (1984): 61-110.

13 Some contemporary writers on the criminal law do not take a utilitarian view at all. They say general obedience to the law is for the public benefit, and obedience to it requires sacrifice on the part of those who set personal desires aside so as to conform with the law; those who break the law therefore arrogate to themselves an advantage as compared with law-abiding citizens, and must in fairness be punished in order to rectify this disparity. (This is sometimes called "the fair-play theory.") See Herbert Morris, On Guilt and Innocence, 1976, 33-34; and various others, e.g., George Sher, Desert (Princeton University Press, 1987); M. Davis, "How to Make the Punishment Fit the Crime," Ethics 93 (1983): 726-52, and "The Relative Independence of Punishment Theory," Law and Philosophy 7 (1988-9): 321-50, and "Harm and Retribution," Philosophy and Public Affairs 15 (1986): 236-56. A somewhat similar view is put forward by Jean Hampton in "The Retributive Idea" in J. Murphy and J. Hampton, Forgiveness and Mercy (Cambridge: Cambridge University Press, 1988). For a critique see R. Wasserstrom in Philosophy and Social 
course, the accused cannot commit another crime if he is in custody, but the main justification for the system is its deterrence value, that the threat of a tough sentence reduces the incidence of crime. Does it? Doubtless for some crimes, done for personal gain, when the individual may calculate the risks of the penalty against the gain from the offense: such as murder by a racketeer, insider trading, and fraud. But a study by the National Research Council found that the statistics show some correlation between greater reliability of law-enforcement and reduced crime rates, with increased severity of legal punishment of doubtful importance. ${ }^{14}$

It is true that the system of punishments is in a way educational (perhaps by conditioning unpleasant punishment to the idea of a certain offense). It tells prospective criminals, in a forceful way, what society thinks of certain offenses - more than any preaching or example - for persons who are already adults. But something less than five years in a prison might have this effect! (At least, five years in prison seems to me a very long time, and

Issues, 1980, 139-46; Hyman Gross, "Unfair Advantage and the Price of Crime," Wayne Law Review 38 (1987): 1395-411; David Dolinko, "Some Thoughts about Retributivism," Ethics 101 (1991): 537-59. The theory has puzzling consequences. Does it imply that mere attempts to commit a crime should be punished not at all? And is the criminal not punished for the particular kind of harm he has done, not on the amount of advantage he may have taken? Do law-abiding citizens suffer from not permitting themselves to commit murder or rape? Or should not all crimes be punished equally, since all are breaches of law? Moreover, it must be recalled that not all criminals have been fairly dealt with by society, having been raised in poverty, and we must ask if the system of law has benefitted them equally. See David Lyons, Ethics and the Rule of Law (Cambridge: Cambridge University Press, 1984), chapter 5; also chapter 3.

14 "Deterrence and Incapacitation: Estimating the Effects of Criminal Sanctions on Crime Rates," 1978, reported in S. H. Kadish, S. J. Schulhofer, and M. G. Paulsen, Criminal Law and its Processes (Boston: Little, Brown and Company, 1983), pp. 197-201. See also J. Andenaes, "The Morality of Deterrence," reprinted in H. Gross and A. von Hirsch, eds, Sentencing (New York: Oxford University Press, 1981), pp. 191-202. 
its imposition seems to require justification!) The late Judge Charles Wyzanski once told the writer that of the hundred or so persons he had sentenced for embezzlement in his years as senior judge of the Federal Court in Boston, he had given everyone a suspended sentence and believed that the effects of the crime on career, publicly known, are deterrence enough. So, do we need a prison sentence for this offense? (Perhaps the threat of some such sentence has some additional deterrent value.) In answer to the question of whether he would do the same for murder, his reply was roughly affirmative, that $80 \%$ of murders are unconnected with a life of crime, and are committed by persons who are uneducated, unaware of the standard moral judgment of acts of murder, or acting from passion, and will never murder again. So what is the point of long sentences? ${ }^{15}$ Again, the threat of a severe punishment for murder may be important to deter those others who commit murder as part of a life of crime. And if the threat is to be effective, the system must make good use of the threat in many cases. I would think that, for most ordinary citizens, deterrence is already at its maximum if one thinks one may be discovered, tried, and one's offense publicized in the newspapers, irrespective of any penalty imposed, a view seconded by John Braithwaite. ${ }^{16}$ (This depends, perhaps, on one's status in the community, and maybe a serious threat is necessary in order to induce everyone to reckon his income tax correctly. Why do people who commit murders really do so? Do they give thought to possible legal sanctions?)

15 Hugo Bedau found that in twelve states, from 1900 to 1976 , of 21,646 persons convicted of murder and subsequently released, only 16 were later convicted of homicide. A later nationwide study showed that, between 1965 and 1974, of 11,404 persons convicted of willful homicide and then released, only 34 committed another murder. In Hugo Bedau, ed., The Death Penalty in America, 3rd ed. (New York: Oxford University Press, 1982), p. 175. See also Anna Quindlen, "Marking Time," New York Times, March 11, 1992, A-16.

${ }_{16}$ John Braithwaite, Crime, Shame, and Reintegration (Cambridge: Cambridge University Press, 1989). 
We should note that $90 \%$ of the inmates of prisons are men, mostly between the ages of 15 and 25 , unmarried, in cities, in areas of high residential mobility, who have done poorly in school and have friendships with criminals, and are at the bottom of the socio-economic ladder and, if already a convicted offender, stigmatized as such. This fact has implications for what should be done to maximize public benefit! What kind of state action/system is most likely to prevent further crime from this group?

If utilitarian considerations are to be used as a basis for evaluating the system of criminal law, either morally, or in line with a Benthamite utilitarianism of the law just as law, with the aim of making changes so as to maximize expectable well-being, drastic changes seem to be called for, contrary to a currently very influential feeling that the laws should be made tougher, more prisons built, and the convicted severely punished for what they did. It appears to me, however, that the way for the law to go, if the aim is to do what it takes to maximize benefit generally (including the benefit of the criminals), at least for offenders not already committed to a life of crime, is (aside from dropping penalties and continuing to classify as "offenses" acts which hardly cause harm - like a physician assisting an ill person to commit suicide, when he clearly wants to do so), to reduce radically sentences of imprisonment, and to make wide use of non-prison sentences, particularly following European practices and the schedules of recent sentencing commissions like those in Minnesota, say, by the use of fines (perhaps deterring sex crimes by an enforced fine of $\$ 5,000$, or a sum depending on the ability of the offender to pay), or this in addition to or replaced by various restrictions on the person's behavior, such as residence in the community or commitment to be in one's home (house arrest, perhaps with electronic monitoring) most hours of the day, or intermittent incarceration (say on weekends), intensive supervision, extensive community service (say, thirty hours of service in place of a month in prison), enrollment in a drug program or therapy in the case of sex offenses, with some training to prepare for a job and assistance in finding one, and perhaps a bit of education about the point of morality and the 
law. All this and more is advocated by Norval Morris and Michael Tonry in a recent volume. ${ }^{17}$ This would also, possibly, be rather less expensive than prison sentences. (One might add that some changes need to be made in the legal education of prospective judges - perhaps one or more courses in the philosophical foundations of morality and the law.) How to get legislative bodies to make changes, along lines evidence shows are needed to maximize public benefit, as contrasted with the commitment to make the law "tougher", is a serious problem. It may not be easy to convince legislators that supervision, therapy, and demands of public service are more likely to benefit the public than being thrust into a penitentiary for a few years, but it seems something must be done to spread such a conviction. The present system not only manifestly fails to maximize the public good, but, from a conscience-utilitarian point of view, is manifestly immoral and failing in humanity.

The foregoing discussion will have made clear that an appraisal of the system of criminal law is markedly a more complex problem than the ones the conscience-utilitarian theory of morality faces in deciding which kinds of conduct are morally wrong. What the rule-utilitarian about morality has to do is simply to determine which moral anti-attitudes should be prevalent and taught in view of the long-run expectable utilities. There is, of course, more, when the basic requirements conflict. Then one has to think what social life would be like if the preference went one way or the other, in general. These problems seemingly can be resolved in the same way, just by taking thought!

An appraisal of the criminal law, just from the point of view of public benefit, is more demanding - not only requiring decision which kind of offense is worse, but also what society should do to maximize social benefit, by imposing and implementing penal-

17 Between Prison and Probation (New York: Oxford University Press, 1990). See also Hyman Gross and A. von Hirsch, Sentencing (New York: Oxford University Press, 1981). 
ties - something that requires knowledge about the probable effects of different strategies, knowledge that the average individual does not have just from thinking about it, but acquiring, which demands some familiarity with the statistics and psychology of criminal behavior and the effects of the penal system.

What I am saying is that an unimpassioned second look, in view of the facts, is called for, on this segment of the criminal law. If the U.S. system of education and its system of health care are in need of reform, how about its system of criminal law?

But there is an area of the criminal law which seems to raise only simpler problems.

\section{JUSTIFICATION}

The criminal law considers whether it may be the case that some behavior, forbidden by the statutes (and interpretations) of the law, is justified in some cases and hence not, finally, a criminal offense at all. (There is another question whether some such behavior may be excused, but not justified. ${ }^{18}$ )

It is quite possible that an optimal morality will prescribe ignoring the normal first-order moral requirements (like not stealing, telling lies) when following such a rule of conscience would do a serious amount of harm. For instance, maybe torture might be permissible if the destruction of New York City by a nuclear bomb is at stake, at least if there is some probability that the right person is in custody. Normal morality does, of course, recognize avoiding harm as a basic moral consideration which normally is stronger than most others (if telling the truth would be hurtful, you had better not be too squeamish about the truth, while recognizing that in the

18 There is controversy about how "justification" should be defined. See Kent Greenawalt, "The Perplexing Borders of Justification and Excuse," Columbia Law Review 84 (1984): 1897-1927; also Law and Contemporary Problems 49 (1986). For helpful discussion see also B. Sharon Byrd, "Wrongdoing and Attribution: Implications Beyond the Justification-excuse Distinction," Wayne Law Review 33 (1987): 1289-342. 
long run truth is advantageous); but what I am suggesting is that if an action would cause really serious harm, its weight is superior to that of any of the normal moral prohibitions, which are appraised by considering whether society would be better off if people were normally motivated in a certain way. However, the point here is that something like this kind of thinking is recognized in the law. In some cases of breach of law it is clear that it is better that people do infringe the statutes, e.g., by actions which strongly promote the public goods, such as burning down a house when necessary in order to prevent a general conflagration, or running a red light in order to rush a seriously ill patient to a hospital. Call this a "defense of necessity." Thus the Model Penal Code (Section 3.02) says that "Conduct which the actor believes to be necessary to avoid a harm or evil to himself or to another is justifiable, provided that (a) the harm or evil sought to be avoided by such conduct is greater than that sought to be prevented by the law defining the offense charged. ..." It should be noted that this statement must be understood carefully, to fit actual legal practice, since it does not say that whether one evil is greater is settled by the "belief" of an agent, but is left to a court, which may account avoidance of an arrest, or any theft, as a considerable evil. (The agent's belief seems relevant only to the effect of his avoidance, not conclusive about how bad it is.) Moreover, it seems that the justification of necessity does not imply, as the foregoing statement seems to, a straight act-utilitarian adjudication $(=$ that it is always acceptable to do what, on the agent's evidence, will maximize the public good) of criminal cases. For a thief cannot justify his stealing on the ground that what is stolen is more important to him than to the owner. If he could, legal protection of property would hardly be possible. So there must be a conscienceutilitarian slant to the law, roughly to the effect that a condition of justification is that a general acceptance of permissibility of a given type of decision would be socially beneficial. Perhaps what the Model Penal Code should say is, at least (for a simple formulation) that the good which justifies must actually, in the judgment of court or jury, be not just greater but that the good of permis- 
sibility of that type of action but be greater than the evil of the type of action which the law normally aims to avoid. (But possibly some vagueness in this rule is called for, so that different types of case may be treated differently.) Would this coincide with the view that (1) normal morality will give considerable weight to harmfulness in deciding the order of permissibility of various actions, but also (2) set aside all this "normal" morality when the good/evil involved is very serious? This issue is doubtless open to debate.

It is generally supposed that an important implication of this provision is the right to self-defense. Thus the Model Penal Code states that the use of force toward "another person is justifiable when the actor believes that such force is immediately necessary for the purpose of protecting himself against the use of unlawful [my italics] force by such other person on the present occasion,"19 except that deadly force may not be used unless "the agent believes that such force is necessary to protect himself against death, serious bodily harm, kidnapping or sexual intercourse compelled by force or threat ...." On the whole, the availability of this kind of defense against prosecution seems well conceived to augment the public good in the long run. For, in the case of self-defense, awareness by a potential aggressor that force against him is legitimate is itself a deterrent factor. This comports with the rule-utilitarian view.

Professor J. J. Thomson, in a recent article, ${ }^{20}$ argues that the

19 For some interesting comments see George Fletcher, "Self-defense as a Justification of Punishment," Cardozo Law Review 12, 859-66; and D. W. Elliott, "Necessity, Duress, and Self-defense," Journal of Criminal Law and Criminology 74 (1983): 343-62.

20 "Self-defense," in Philosophy and Public Affairs 20 (1991): 283-310; see also The Realm of Rights (Cambridge, Mass.: Harvard University Press, 1990), chap. 14. See Larry Alexander, "Self-defense, Justification, and Excuse," Philosophy and Public Affairs 22 (1993): 53-66.

W. D. Ross, in a rather qualified way, seems to hold that a person's failure to respect the rights of others abolishes his own corresponding rights. See The Right and the Good (Oxford, 1930), pp. 60-61, also pp. 54-56. But a person hardly fails to "respect" the rights of others by an unintentionally threatening form of behavior. 
justifiability (whether moral or legal) of killing in self-defense lies in the fact that every nonaggressor has a right not to be killed, which another is violating by a threat he poses. But, she holds, when a person is a threat to your life (intentionally or not), his right not to be killed by you vanishes - is forfeited. That is why you may defend yourself by killing him. (This defense, according to her, applies to killing a fat man unintentionally falling on you, who is sure to kill you if his fall is not deflected, a case in which, I suggest, an excuse of duress might be more reasonable.)

Unlike a utilitarian view of the law, which would permit killing an aggressor on the ground that this right to kill is a deterrent, Thomson's view affirms but does not explain why there is a right to kill a person who endangers but is not an unlawful aggressor. Thomson's answer seems to be just that we do have such a right and that we can see that we do: that is a necessary truth. ${ }^{21}$ In this she seems to have the support of the Model Penal Code in an obscure and complex clause permitting such a defense -3.11 (1). This view seems to be seconded by George Fletcher, apparently partly in deference to Continental legal theory, according to which "the innocent aggressor infringes upon the integrity and autonomy of the resister" and therefore the threat's conduct is "wrong and the resister's is right." 22 Doubtless there are some exceptions to my suggestion that the attacker must be culpable: the attacker might be guiltless because of mistake or insanity, and in this case security considerations might well prevail, perhaps not as a justification, but at least as excusing on grounds of duress.

Dept. of Philosophy,

University of Michigan (emeritus)

21 See her 1990, Introduction, pp. 4-5, 15-20, 32-3.

22 L. A. Alexander, "Justification and Innocent Aggressors," Wayne Law Review, 1987, 1177-89, especially 1178-80; George Fletcher, Rethinking the Criminal Law. 860-64; and M. Bayles, Principles of Law (Dordrecht: Reidel, 1987), p. 334. 